\title{
GAMBARAN PENGETAHUAN MASYARAKAT TENTANG PROTOKOL KESEHATAN DAN KEPATUHAN MENJALANKAN PROTOKOL KESEHATAN PADA MASA PANDEMI COVID-19 DI KELURAHAN LANGGINI
}

\author{
Rinda Fithriyana ${ }^{1}$, Alini ${ }^{2}$ \\ Program Studi Sarjana Kewirausahaan, Universitas Pahlawan Tuanku Tambusai ${ }^{1}$ \\ Program Studi Sarjana Keperawatan, Universitas Pahlawan Tuanku Tambusai ${ }^{2}$ \\ rindaup@gmail.com¹,alini_09@yahoo.com²
}

\begin{abstract}
COVID-19 is a disease that currently affects the entire population of the world. Preventive efforts in the health protocols implemented by the community in breaking the chain of transmission of COVID 19 during the new normal period are by getting used to wearing masks, washing hands with soap (handsanitanizer), maintaining distance (social distancing), staying away from crowds and avoiding traveling outside the area. especially areas that have been declared as red zones. But in reality, they are not very obedient in implementing government appeals and instructions regarding health protocols in handling COVID 19. This study aims to describe the public's knowledge about health protocols and compliance with health protocols during the Covid-19 pandemic in Langgini Village. The design used in this research is descriptive analysis. The population in this study was the entire community in Langgini Village, Bangkinang Health Center Working Area, Kampar Regency with a total adult population of 3,885 people. The sampling technique used is simple random sampling with a total sample of 97 people. The data collection tool uses a questionnaire. Based on the results of the study, it is known that most of the respondents have good knowledge about health protocols, as many as 68 respondents $(70.1 \%)$, most of the respondents comply with health protocols, as many as 59 respondents (58.8\%). It is hoped that the health program manager will increase the provision of information regarding the importance of complying with health protocols to reduce the spread of COVID 19.
\end{abstract}

\section{Keywords $\quad:$ Covid-19, Compliance, Knowledge, Health Protocol}

\begin{abstract}
ABSTRAK
COVID 19 merupakan penyakit yang saat ini diderita oleh seluruh penduduk didunia. Upaya preventif dalam protokol kesehatan yang diterapkan masyarakat dalam memutus mata rantai penularan COVID 19 pada masa new normal yaitu dengan membiasakan diri memakai masker, mencuci tangan pakai sabun (handsanitanizer), menjaga jarak (social distancing), menjauhi keramaian dan menghindari berpergian ke luar daerah, terutama daerah-daerah yang sudah dinyatakan sebagai zona merah. Namun pada kenyataannya, tidak begitu patuh dalam menerapkan himbauan dan instruksi pemerintah terkait protokol kesehatan dalam penanganan COVID 19. Penelitian ini bertujuan untuk mengetahui gambaran pengetahuan masyarakat tentang protokol kesehatan dan kepatuhan menjalankan protokol kesehatan pada masa pandemi Covid-19 di Kelurahan Langgini. Desain yang digunakan dalam penelitian ini adalah analisis deskriptif. Populasi dalam penelitian ini adalah seluruh masyarakat di Kelurahan Langgini Wilayah Kerja Puskesmas Bangkinang Kota Kabupaten Kampar dengan jumlah penduduk usia dewasa sebanyak 3.885 orang. Teknik pengambilan sampel menggunakan simple random sampling dengan jumlah sampel sebanyak 97 orang. Alat pengumpulan data menggunakan kuesioner. Berdasarkan hasil penelitian diketahui bahwa sebagian besar responden memiliki pengetahuan yang baik tentang protokol kesehatan, yaitu sebanyak 68 responden $(70,1 \%)$, sebagian besar responden patuh menjalankan protokol kesehatan, yaitu sebanyak 59 responden $(58,8 \%)$. Diharapkan kepada bagian pengelola program kesehatan agar meningkatkan pemberian informasi mengenai pentingnya mematuhi protokol kesehatan untuk mengurangi penyeberan COVID 19.
\end{abstract}

Kata Kunci : Covid-19, Kepatuhan, Pengetahuan, Protokol Kesehatan 


\section{PENDAHULUAN}

COVID 19 merupakan penyakit yang saat ini diderita oleh seluruh penduduk didunia. Penderita COVID 19 perbulan Desember 2020 yang dinyatakan positif diseluruh dunia diperkirakan ada 116 juta orang, kasus kematian mencapai 2,5 juta orang, sedangkan sebanyak 223 negara terkena dampak dari COVID 19 ini (WHO, 2021). Di Indonesia, COVID 19 mulai masuk pada bulan Januari tahun 2020 dan mulai terkonfirmasi penderita yang terdampak pada bulan Maret 2020. sebanyak 1,3 juta orang penduduk Indonesia dinyatakan positif terkena virus COVID 19 ini, sedangkan sebanyak 1,2 juta orang penduduk Indonesia dinyatakan sembuh dari virus COVID 19 dan sebanyak 3 ribu orang meninggal akibat virus COVID 19 (Kemenkes, 2021). Di Provinsi Riau perbulan Desember penderita COVID 19 yang terkonfirmasi sebanyak 32 ribu orang, sedangkan yang dinyatakan sembuh sebanyak 30 ribu orang, penderita COVID 19 yang dirawat sebanyak 285 orang, yang melakukan isolasi mandiri sebanyak 691 orang dan yang dinyatakan meninggal sebanyak 781 orang (Dinas Kesehatan Provinsi Riau, 2021). Berdasarkan data Dinas Kesehatan Kabupaten Kampar tahun 2020, di Kabupaten Kampar tercatat sebanyak $3811(49,51 \%)$ kasus pada tahun 2020 (Dinas Kesehatan Provinsi 2020). Pada 10 Kecamatan di Kabupaten Kampar, jumlah penderita COVID 19 tertinggi ke 2 berada di Kecamatan Bangkinang Kota. Hal ini terlihat jumlah penderita COVID 19 Sebanyak 151 (19,69\%). Sedangkan di wilayah kerja Puskesmas Bangkinang Kota, penderita COVID 19 tertinggi adalah Kelurahan Langgini yaitu tercatat sebanyak $137(41,3 \%)$ kasus pada tahun 2020.

Beberapa gejala klinis umum COVID 19 adalah demam, batuk kering, dan kelelahan, namun ditemukan bukti bahwa sebagian pasien COVID 19 tidak menunjukkan gejala (Gao et al., 2020). Sekitar 80\% pasien COVID 19 sembuh dari penyakit tanpa memerlukan perawatan khusus di rumah sakit. Tingkat keparahan penyakit meningkat pada lansia dan yang mempunyai penyakit penyerta seperti hipertensi, penyakit jantung, diabetes, kanker, dan penyakit paru kronis. Namun, siapapun dapat terinfeksi COVID 19 dan berkembang menjadi penyakit yang berat (WHO, 2020). Seseorang dapat terinfeksi COVID 19 melalui kontak langsung atau tidak langsung melalui droplet saluran napas orang yang terinfeksi (Lotfi, Hamblin and Rezaei, 2020).

Droplet yang keluar saat batuk, bersin, atau berbicara dari orang yang terinfeksi dapat menyebabkan penularan secara langsung. Virus dapat masuk melalui mulut, hidung, dan mata seseorang yang berada dalam jarakyang dekat dan melakukan kontak erat dengan orang yang terinfeksi. Selain itu, penularan melalui kontak tidak langsung juga dapat terjadi, yaitu saat menyentuh benda atau permukaan yang sudah terkontaminasi oleh virus kemudian menyentuh mata, hidung, atau mulut tanpa mencuci tangan terlebih dahulu (Lotfi, Hamblin and Rezaei, 2020).

Pemerintah juga mengeluarkan kebijakan penerapan karantina negara, karantina wilayah, dan Pembatasan Sosial Berskala Besar (PSBB) bagi wilayahwilayah yang berstatus zona merah, dan terakhir mengingat besarnya dampak perekonomian dari status PSBB maka pemerintah mengeluarkan kebijakan New Normal dengan memperhatikan protokol kesehatan terkait COVID 19. Upaya preventif dalam protokol kesehatan yang diterapkan masyarakat dalam memutus mata rantai penularan COVID 19 pada masa New Normal yaitu dengan membiasakan diri memakai masker, mencuci tangan pakai sabun (handsanitanizer), menjaga jarak (social distancing), menjauhi keramaian dan menghindari berpergian ke luar daerah, terutama daerah-daerah yang sudah dinyatakan sebagai zona merah (Hamdani, 2020).

Menurut Kozier (2010) kepatuhan adalah perilaku sesuai anjuran terapi dan kesehatan dan dapat dimulai dari tindak 
mengindahkan setiap aspek anjuran hingga mematuhi rencana. Sedangkan Ian \& Marcus (2011) menyatakan bahwa kepatuhan mengacu kepada situasi ketika perilaku seorang individu sepadan dengan tindakan yang dianjurkan atau nasehat yang diusulkan oleh seorang praktisi kesehatan atau informasi yang diperoleh dari suatu sumber informasi lainnya.

Banyak faktor yang mempengaruhi terbentuknya kepatuhan seseorang, dimana Kozier (2010) menyatakan bahwa kepatuhan dipengaruhi oleh beberapa faktor antara lain motivasi, tingkat perubahan gaya yang dibutuhkan, persepsi keparahan masalah kesehatan, pengetahuan, dampak dari perunahan, budaya, dan tingkat kepuasan serta kualitas pelayanan kesehatan yang diterima. Sedangkan Kamidah (2015) menyebutkan faktor yang mempengaruhi kepatuhan seseoorang berupa pengetahuan, motivasi, dan dukungan keluarga.

Almi (2020) menyatakan bahwa kepatuhan dapat ditingkatkan melalui peningkatkan kesadaran masyarakat dengan komunikasi efektif melalui berbagai media dan metode yang sesuai dengan keragaman masyarakat. Kampanye yang lebih jelas dan terarah, mempermudah akses kesehatan dengan informasi yang jelas dan terusmenerus. Sehingga masyarakat cepat melakukan tindakan pemeriksaan,pengobatan dan isolasi mandiri ketika terinfeksi serta kebijakan yang konsisten sehingga tidak membingungkan masyarakat.

Namun pada kenyataannya, Hamdani (2020) menyatakan bahwa masyarakat tidak begitu patuh dalam menerapkan himbauan dan instruksi pemerintah terkait protokol kesehatan dalam penanganan COVID 19. Bahkan ada orang-orang yang menganggap remeh dan mengabaikan, keadaan ini dipengaruhi oleh mental, karakter, tingkat pendidikan, pekerjaan dan lingkungan tempat tinggal.

Berdasarkan hasil survey awal berupa wawancara yang peneliti lakukan terhadap 10 responden di Kelurahan Langgini diketahui bahwa 7 responden tidak mengetahui tentang pengertian protokol kesehatan, serta responden mengatakan tidak ada motivasi untuk menjalankan protokol kesehatan dan tidak patuh dalam menjalankan protokol kesehehatan. Sehingga tindakan yang dilakukannya bisa mencegah terjadinya penularan COVID 19 dan responden beranggapan bahwa COVID 19 hanyalah penyakit biasa yang tidak perlu dicegah. Sedangkan 3 responden mengetahui tentang pengertian protokol kesehatan serta mempunyai motivasi untuk menjalankan protokol kesehatan, sehingga mereka patuh untuk menjalankan protokol kesehatan dan mengetahui tindakan yang bisa mencegah terjadinya penularan COVID 19 dan responden mengatakan penyakit COVID 19 merupakan penyakit yang berbahaya dan harus dicegah agar tidak mengganggu aktivitas sehari-hari dan dapat menurunkan angka penderita COVID 19 didaerahnya.

Maka berdasarkan latar belakang diatas, sehingga penulis tertarik melakukan penelitian tentang gambaran pengetahuan masyarakat tentang protokol kesehatan dan kepatuhan menjalankan protokol kesehatan pada masa pandemi Covid-19 di Kelurahan Langgini.

\section{METODE}

Penelitian ini menggunakan pendekatan penelitian kuantitatif non eksperimen dengan skala sebagai alat ukur. Desain yang digunakan dalam penelitian ini adalah analisis deskriptif, yaitu desain penelitian yang dilakukan terhadap sekumpulan objek yang biasanya bertujuan untuk melihat gambaran fenomena (kesehatan) yang terjadi didalam suatu populasi tertentu (Notoatmodjo, 2015).

Penelitian ini dilakukan di di Kelurahan Langgini Wilayah Kerja Puskesmas Bangkinang Kota. Penelitian dilakukan pada Bulan Juni - Juli tahun 2021. Populasi dalam penelitian ini adalah seluruh masyarakat di Kelurahan Langgni Wilayah Kerja Puskesmas Bangkinang Kota Kabupaten Kampar dengan jumlah 
penduduk usia dewasa sebanyak 3.885 orang. Sampel pada penelitian ini yaitu masyarakat yang menetap dikelurahan Langgini Wilayah Kerja Puskesmas Bangkinang Kota Kabupaten Kampar. Teknik pengambilan sampel pada penelitian ini adalah simple random sampling, yaitu pengambilan sampel secara acak dengan menggunakan rumus Slovin. Berdasarkan penerhitungan, jumlah sampel yang dibutuhkan sebanyak 97 orang.

Alat pengumpulan data yang digunakan pada penelitian yaitu berupa kuesioner. Untuk mengetahui pengetahuan masyarakat tentang protokol kesehatan, peneliti menggunakan multiple choice yang terdiri dari 10 pertanyaan tertutup, artinya semua jawaban sudah disediakan oleh peneliti dan responden hanya tinggal memilih jawaban yang benar atas pertanyaan yang dianjurkan. Jika responden menjawab dengan benar atas pertanyaan yang diajukan, maka diberi skor (1) sedangkan jika jawaban salah diberi skor (0). Untuk mengetahui tingkat kepatuhan msayarakat dalam menjalankan protokol kesehatan COVID 19, peneliti menggunakan skala likert yang terdiri dari 8 pertanyaan. Analisa data Analisis data dalam penelitian ini menggunakan analisa univariat. Analisa univariat bertujuan untuk menjelaskan atau mendeskripsikan karakteristik setiap variabel penelitian.

\section{HASIL}

\section{Karakteristik Responden}

Karakteristik reponden terdiri dari umur, jenis kelamin dan pekerjaan. Karakteristik responden merupakan data kategorik sehingga dianalisis dengan menghitung distribusi frekuensinya.

Berdasarkan tabel 1 dapat dilihat bahwa dari keseluruhan 97 responden, $(64,9 \%)$ berada pada rentang umur 18-35 tahun, sebanyak 80 responden $(82,5 \%)$ berjenis kelamin laki-laki, dan sebanyak 64 responden $(66 \%)$ mempunyai pekerjaan sebagai wiraswasta
Tabel 1 Distribusi Frekuensi Responden

Berdasarkan Umur, Jenis

Kelamin dan Pekerjaan di

Kelurahan Langgini Kabupaten Kampar

\begin{tabular}{|c|c|c|}
\hline Karakteristik & $\begin{array}{c}\text { Frekuensi } \\
\text { (N) }\end{array}$ & $\begin{array}{c}\text { Persentase } \\
(\%)\end{array}$ \\
\hline \multicolumn{3}{|l|}{ Umur } \\
\hline 18-35 Tahun & 63 & $64,9 \%$ \\
\hline 36-55 Tahun & 34 & $35,1 \%$ \\
\hline
\end{tabular}

\begin{tabular}{llc}
\hline Jumlah & 97 & $100 \%$ \\
\hline Jenis Kelamin & & \\
a. Laki-laki & $\mathbf{8 0}$ & $\mathbf{8 2 , 5 \%}$ \\
b. Perempuan & 17 & $17,5 \%$ \\
\hline Jumlah & 97 & $100 \%$ \\
\hline Pekerjaan & & \\
a. Wiraswasta & $\mathbf{6 4}$ & $\mathbf{6 6 , \%}$ \\
b. Petani & 23 & $23,7 \%$ \\
c. PNS & 10 & $10,3 \%$ \\
$\quad$ Jumlah & & \\
& &
\end{tabular}

\section{Analisa Univariat}

Untuk menggambarkan pengetahuan masyarakat tentang protokol kesehatan dan kepatuhan menjalankan protokol kesehatan dianalisis menggunakan analisa univariat.

Tabel 2:Distribusi Frekuensi Responden Berdasarkan Pengetahuan

\begin{tabular}{cccc}
\hline No & Pengetahuan & Frekuensi & $\begin{array}{c}\text { Persentase } \\
(\%)\end{array}$ \\
\hline $\mathbf{1}$ & Baik & $\mathbf{6 8}$ & $\mathbf{7 0 , 1 \%}$ \\
2 & Kurang & 29 & $29,9 \%$ \\
& Total & 97 & $100 \%$ \\
\hline
\end{tabular}

Dari tabel 2 dapat diketahui, sebagian besar responden memiliki pengetahuan yang baik tentang protokol kesehatan, yaitu sebanyak 68 responden $(70,1 \%)$.

\section{Tabel 3:Distribusi Frekuensi Responden Berdasarkan Kepatuhan}

\begin{tabular}{ccc}
\hline Kepatuhan & Frekuensi & $\begin{array}{c}\text { Persentase } \\
(\mathbf{\%})\end{array}$ \\
\hline Patuh & $\mathbf{5 9}$ & $\mathbf{6 0 , 8 \%}$ \\
Tidak Patuh & 38 & $39,2 \%$ \\
Total & 97 & $100 \%$ \\
\hline
\end{tabular}


Dari tabel 3 dapat diketahui, sebagian besar responden patuh menjalankan protokol kesehatan, yaitu sebanyak 59 responden $(58,8 \%)$

\section{PEMBAHASAN}

Berdasarkan hasil penelitian diperoleh bahwa pengetahuan masyarakat tentang protokol kesehatan sebagian besar 70,1\% berada pada kategori baik yaitu sebanyak 68 responden. Hal ini diduga disebabkan oleh umur responden pada masa dewasa awal yaitu pada rentang 18-40 tahun sebanyak 63 responden $(64,9 \%)$, pekerjaan responden sebagian besar wiraswasta yaitu sebanyak 64 responden (66\%), serta hal ini juga dapat disebabkan karena kurangnya informasi yang diperoleh oleh masyarakat tentang protokol kesehatan dari tenaga kesehatan maupun dari media cetak dan media masa khususnya tentang protokol kesehatan.

Pengetahuan seseorang salah satunya dipengaruhi oleh umur terhadap memori atau daya ingat seseorang. Dari uraian ini dapat disimpulkan bahwa bertambahnya umur seorang dapat berpengaruh pada bertambahnya pengetahuan yang diperoleh tetapi pada umur-umur tertentu atau menjelang usia lanjut kemampuan penerimaan atau pengingatan suatu pengetahuan akan berkurang (Ahmadi, 2004).

Mubarak (2004) juga mengemukakan bahwa pengetahuan seseorang dapat dipengaruhi oleh umur, umur dapat memberikan pengaruh pengaruh pertama bagi seseorang dimana seseorang dapat mempelajari hal-hal yang baik dan juga halhal yang buruk tergantung pada sifat kelompoknya. Dalam bertambahnya umur seseorang akan memperoleh pengalaman yang akan berpengaruh pada cara berfikir dan pengetahuan.

Hal ini sesuai dengan yang disampaikan oleh Meliono dan Irmayanti (2007) yang menjelaskan bahwa faktor yang mempengaruhi pengetahuan dalam diri seseorang dapat dipengaruhi oleh 3 hal yaitu umur, informasi dan media. Menurut Ahmadi (2004) pengetahuan seseorang salah satunya dipengaruhi oleh umur terhadap memori atau daya ingat seseorang. Dari uraian ini dapat disimpulkan bahwa bertambahnya umur seorang dapat berpengaruh pada bertambahnya pengetahuan yang diperoleh tetapi pada umur-umur tertentu atau menjelang usia lanjut kemampuan penerimaan atau pengingatan suatu pengetahuan akan berkurang.

Mubarak (2004) mengemukakan pengetahuan seseorang dapat dipengaruhi juga oleh pekerjaan, pekerjaan dapat memberikan pengaruh pengaruh pertama bagi seseorang dimana seseorang dapat mempelajari hal-hal yang baik dan juga halhal yang buruk tergantung pada sifat kelompoknya. Dalam pekerjaan seseorang akan memperoleh pengalaman yang akan berpengaruh pada cara berfikir dan pengetahuan.

Menurut Notoatmodjo (dalam Moudy \& Syakurah, 2020), pengetahuan merupakan suatu domain kognitif yang sangat berpengaruh dalam membentuk tindakan seseorang. Penerimaan terhadap perilaku baru akan lebih mudah bila didasarkan oleh pengetahuan, sedangkan perilaku tersebut tidak akan bertahan lama tanpa didasarkan oleh pengetahuan.

Menurut Suryati \& Ika dalam (Sastrawinata, 2011) saat kita semakin mengenal diri kita, kita memahami apa yang dirasakan dan lakukan. Pemahaman itu akan memberikan kita kesempatan atau kebebasan untuk mengubah hal-hal yang kita ubah mengenai diri kita dan menciptakan kehidupan yang kita inginkan. Masyarakat yang mengenal dan memahami dirinya akan melakukan apa yang terbaik untuk dirinya termasuk mematuhi dan mentaati peraturan yang berlaku di masa pandemi Covid-19 saat ini.

Menurut Tirta (2020) beberapa masyarakat mengatakan sudah mulai bosan dengan menerapkan protokol kesehatan. Mereka mengatakan ketika mereka sudah menerapkan protokol kesehatan seperti 
memakai masker, menjaga jarak dan mencuci tangan akan tetapi angka penyebaran virus COVID 19 terus bertambah setiap harinya.

Sedangkan menurut Ravariando (2020), pada masyarakat saat ini sedang terjadi suatu fenomena caution fatigue, yaitu suatu keadaan yang membuat seseorang dipenuhi rasa jenuh. Ketika sudah dijejali dengan perasaan negatif, motivasi atu minat menjadi lebih rendah untuk mengambil tindakan pencegahan.

\section{KESIMPULAN}

Dari hasil penelitian maka dapat ditarik kesimpulan bahwa pengetahuan masyarakat tentang protokol kesehatan di Kelurahan Langgini Kabupaten Kampar sebagian besar pada kategori baik yaitu $70,1 \%$., dan kepatuhan masyarakat menjalankan protokol kesehatan di Kelurahan Langgini Kabupaten Kampar sebagian besar pada kategori patuh yaitu $66 \%$.

\section{UCAPAN TERIMAKASIH}

Terimakasih peneliti ucapakan pada semua pihak yang telah berkontribusi terhadap penelitian ini. Serta pada Universitas pahlawan Tuanku Tambusai.

\section{DAFTAR PUSTAKA}

Almi. (2020). Analisis Penyebab Masyarakat tidak patuh pada protocol Covid-19. diakses pada tanggal 13 Agustus 2020 dari https://almi.or.id/2020/06/05/analisispenyebab-masyarakat-tidak-patuhpada-protokol-covid-19

Dinas Kesehatan Provinsi Riau. (2020). Data statistik corona provinsi Riau tahun 2021. Pekanbaru: Dinas Kesehatan Provinsi Riau.

Dinas Kesehatan Kabupaten Kampar. (2020). Jumlah Covid -19 tertinggi dibeberapa kecamatan di kabupaten kampar tahun 2020. Bangkinang: Dinas kesehatan kabupaten kampar.
Hamdani. (2020). Kepatuhan Sosial di Era New Normal. diakses pada 13 Agustus 2020 dari https://www.ajnn.net/news/kepatuhansosial-di-era-new-normal/index.html

Ian \& Marcus (2011). Psikologi Kesehatan Panduan Lengkap dan Komprehensif Bagi Studi Psikologi Kesehatan. Cetakan I. Yogyakarta : Palmall.

Kamidah. (2015). Faktor-faktor yang mempengaruhi kepatuhan ibu hamil dalam mengkonsumsi tablet besi di Puskesmas Simo Boyolali. Skripsi: Stikes Aisyiyah

Kementerian Kesehatan Indonesia. (2021). Kesiapsiagaan menghadapi infeksi Covid

19.https://kemkes.go.id/article/view/2 0031700001/Dokumen-

ResmidanProtokol-Penanganan-

COVID-19.html. Diakses pada tanggal 6 maret 2021.

Kementerian Dalam Negeri RI. (2020).

$\begin{array}{lcr}\text { Pedoman } & \text { Manajemen } & \text { Bagi } \\ \text { Pemerintah } & \text { Daerah } & \text { Dalam } \\ \text { Penanganan } & \text { COVID-19 } & \text { dan } \\ \text { Dampaknya. } & & \end{array}$

Kementerian Kesehatan RI (2020). Dashboard Data Kasus COVID-19 di Indonesia. diakses pada tanggal 5 Agustus $2020 \quad$ pada https://www.kemkes.go.id/article/vie w/ 20031900002/Dashboard-DataKasus-COVID-19-di-Indonesia.html

Notoatmodjo, S. (2015). Metodologi Penelitian Kesehatan. Jakarta: PT Rineka Cipta

UPT BLUD Puskesmas Bangkinang. (2020). Laporan Covid -19 di Wilayah Kerja UPT BLUD Puskesmas Bangkinang Tahun 2020. Bangkinang: UPT BLUD Puskesmas Bangkinang.

World Health Organization. (2020). Corona Virus disease (Covid -19) Pandemic.https://www.who.int/emerg encies/diseases/novelcoronavirus2019. Diakses tanggal 6 Maret 2021 